\title{
Plejotopowe działanie witaminy D
}

\section{Pleotropic effect of vitamin D}

\author{
Marta Marcinkowska, Agnieszka Mickiewicz, Marcin Fijałkowski \\ I Katedra i Klinika Kardiologii Gdańskiego Uniwersytetu Medycznego
}

\section{STRESZCZENIE}

Liczne badania naukowe z ostatnich lat, podkreślające wielopłaszczyznowe działanie witaminy $D$, ugruntowały silną pozycję zaleceń jej suplementacji w populacji ogólnej oraz grupach ryzyka niedoborów od pierwszych dni życia do późnej starości. Podstawowymi źródłami cholekalcyferolu są synteza skórna oraz wchłanianie jelitowe. Za najlepszy wykładnik zaopatrzenia organizmu w witaminę D uznaje się stężenie w osoczu metabolitu 25(OH)D o długim okresie półtrwania w surowicy krwi. Standardem diagnostycznym powinno być równoczesne oznaczanie $25(\mathrm{OH}) \mathrm{D}_{2}$ oraz $25(\mathrm{OH}) \mathrm{D}_{3}$, czyli 25(OH)D całkowitej. W aktualnych zaleceniach nie rekomenduje się rutynowego oznaczania stężenia witaminy $\mathrm{D}$ w populacji ogólnej, a jedynie w grupach ryzyka niedoborów. Terapia witaminą D związana z prewencją krzywicy zakłada dążenie do wartości 25(OH)D $20 \mathrm{ng} / \mathrm{ml}$ w osoczu, natomiast leczenie uwzględniające jej plejotropowe działanie na inne układy organizmu wskazuje na docelowe stężenie 30-50 ng/ml. Dawki profilaktyczne powinny zależeć od wieku, masy ciała, stopnia nasłonecznienia związanego z porą roku i ekspozycji na słońce oraz uwarunkowań indywidualnych, takich jak dieta i styl życia. Dawka profilaktyczna dla osoby dorosłej (19.-65. r.ż.) o prawidłowej masie ciała wynosi 800-2000 j.m./dobę. Mimo wzrostu spożycia suplementów zawierających cholekalcyferol, szacowany niedobór witaminy D w populacji europejskiej według badań epidemiologicznych utrzymuje się na poziomie 50-70\%, a w Polsce - około $90 \%$. W przypadkach potwierdzonego laboratoryjnie

Adres do korespondencji: lek. Marta Marcinkowska

I Katedra i Klinika Kardiologii

Uniwersyteckie Centrum Kliniczne w Gdańsku

ul. Dębinki 7, 80-952 Gdańsk

tel. 583492504 , faks 583461201

e-mail:marmarta@gumed.edu.pl niedoboru witaminy $D$ (stężenia 25(OH)D $<20 \mathrm{ng} / \mathrm{ml}$ ) leczenie powinno trwać do uzyskania poziomu $30-50 \mathrm{ng} /$ /ml. Wybór odpowiedniej strategii terapeutycznej należy opierać na analizie indywidualnego statusu zdrowotnego pacjenta, wieku, masy ciała oraz nawyków żywieniowych.

Choroby Serca i Naczyń 2019, 16 (1), 45-52

Słowa kluczowe: witamina $D$, niedobór witaminy $D$, plejotropizm

\section{ABSTRACT}

Numerous scientific reports highlighting multiplanar activity of vitamin D, strengthened position of its supplementation guidelines for general population and groups at risk of deficiency from the first day of life until the late senility. Skin synthesis and intestinal absorption are the basic sources of cholecalciferol. The best vitamin D status indicator is the concentration of long half-life 25(OH)D metabolite in the serum. The diagnostic standard should be simultaneous assay of $25(\mathrm{OH}) \mathrm{D}_{2}$ and $25(\mathrm{OH}) \mathrm{D}_{3}$, that is total $25(\mathrm{OH}) \mathrm{D}$. Current guidelines do not recommend the routine $25(\mathrm{OH}) \mathrm{D}$ concentration screening in the general population, but in groups at risk of deficiency only. Therapy based on calcium and phosphorus metabolism, related to rackets prevention, assumes the target $25(\mathrm{OH}) \mathrm{D}$ concentration of $20 \mathrm{ng} / \mathrm{ml}$. The treatment focusing on pleiotropic effect of vitamin $D$ recommends the target concentration of $\mathbf{3 0 - 5 0 ~} \mathrm{ng} / \mathrm{ml}$. Prophylactic doses should depend on age, body weight, seasonal insolation level, sun exposure and individual determinants such as diet and lifestyle. The prophylactic dose for an adult (19-65 years) with normal body weight is $800-2000 \mathrm{IU} /$ day. Notwithstanding, the increase of intake of dietary supplements containing 
cholecalciferol, epidemiological studies estimate the vitamin $\mathrm{D}$ deficiency between 50 and $\mathbf{7 0 \%}$ in the European population, and $90 \%$ in Poland. Treatment of clinically confirmed deficiency $(25(\mathrm{OH}) \mathrm{D}<20 \mathrm{ng} / \mathrm{ml})$ should be continued until the concentration of 30-50 ng/ $/ \mathrm{ml}$. The proper therapeutic strategy choice should be

\section{WPROWADZENIE}

Witamina D w ostatnich latach przeżywa swoisty renesans. W licznych pracach naukowych dowiedziono, że wpływa nie tylko na gospodarkę wapniowo-fosforanową. Obecnie podkreśla się plejotropowe działanie witaminy D poprzez wpływ na ekspresję od 2000 do nawet 3000 genów. Aktywną postać tej witaminy (1,25-hydroksycholekalcyferol) uznano za substancję o działaniu hormonalnym. Zrozumienie jej funkcji na poziomie molekularnym, roli w przekaźnictwie międzykomórkowym oraz wpływie na mechanizmy wzrostu komórkowego i apoptozy otwiera nowe możliwości terapeutyczne. Mimo że pojawiają się głosy sceptycyzmu, a nawet krytyki, dążenie do utrzymania odpowiedniego stężenia witaminy D w osoczu weszło na stałe do rekomendacji i wytycznych profilaktyki oraz leczenia wielu chorób [1].

\section{MECHANIZM DZIALANIA i PLEJOTROPIZM}

Pojęcie "witamina D” obejmuje rozpuszczalne w tłuszczach związki sterolowe, mające nieaktywną biologicznie formę prohormonów - głównie cholekalcyferol (witamina $D_{3}$ ) oraz w mniejszym stopniu ergokalcyferol (witamina $\mathrm{D}_{2}$ ). Podstawowym źródłem cholekalcyferolu jest synteza skórna z 7-dehydrocholesterolu pod wpływem promieniowania ultrafioletowego B (UVB, ultraviolet B; 280-320 nm) w keratynocytach oraz wchłanianie w jelicie cienkim z pokarmem za pośrednictwem chylomikronów do układu limfatycznego. Jest to postać biologicznie nieczynna, a pełną aktywność hormonalną zyskuje przez dwuetapową hydroksylację. Po przyłączeniu do globuliny wiążącej witaminę $\mathrm{D}(\mathrm{DBP}$, vitamin D-binding protein) cholekalcyferol jest transportowany do wątroby, gdzie za pośrednictwem 25-hydroksylazy $\mathrm{D}_{3}$ (CYP2R1, cytochrome P450 family 2 subfamily $R$ member 1) zachodzi jej pierwszy etap. Powstała 25 -hydroksywitamina D $\left(25(\mathrm{OH}) \mathrm{D}_{3}\right.$, calcidiol) to główny metabolit witaminy $\mathrm{D}$, a jego stężenie w osoczu uważa się za główny wskaźnik zaopatrzenia organizmu i wykorzystuje w praktyce klinicznej. Z kolei based on one's individual health outcome concerns, age, body weight and dietary habits.

Choroby Serca i Naczyń 2019, 16 (1), 45-52

Key words: vitamin D, vitamin D deficiency, pleotropic effect

1- $\alpha$-hydroksylaza 25-hydroksywitaminy D (CYP27B1) odpowiada za przemianę $\mathrm{w}$ nerkach do aktywnej hormonalnie postaci $1,25(\mathrm{OH})_{2} \mathrm{D}_{3}$, czyli kalcytriolu. Poziom witaminy D regulowany jest przez 25-hydroksylazę (CYP24A1), która prowadzi do unieczynnienia form aktywnych i ich wydalania [2-4]. Działanie $1,25(\mathrm{OH})_{2} \mathrm{D}$ zachodzi za pośrednictwem wewnątrzkomórkowych receptorów dla witaminy $\mathrm{D}(\mathrm{VDR}$, vitamin $\mathrm{D}$ receptor), które, według różnych źródeł, wraz z koreceptorami odpowiadają za ekspresję od 2000 do nawet 3000 genów [3,5]. Właśnie w obecności VDR oraz 25(OH)D-1 $\alpha$-hydroksylazy (CYP27B1) w wielu tkankach, pozwalającej na pozanerkową syntezę aktywnej $1,25(\mathrm{OH})_{2} \mathrm{D}$, upatruje się jej plejotropowe działanie. Uczestnictwo $25(\mathrm{OH}) \mathrm{D}$ w szlakach endokrynnych, autokrynnych i parakrynnych wydaje się kluczowe dla obniżania ryzyka rozwoju nowotworów, chorób autoimmunologicznych, takich jak stwardnienie rozsiane czy cukrzyca typu 1, astmy oskrzelowej, chorób układu sercowo-naczyniowego, udarów mózgu, cukrzycy typu 2, tocznia rumieniowatego układowego, atopowego zapalenia skóry, zaburzeń neuropoznawczych (w tym w choroby Alzheimera i autyzmu) $[3,6,7]$. Ponadto $25(\mathrm{OH}) \mathrm{D}$ obniża zapadalność na nawracające infekcje, w tym gruźlicę, a nawet ryzyko komplikacji okołoporodowych. Redukuje ryzyko upadków, osteoporozy i złamań, krzywicy i osteomalacji, a co więcej może wpływać na zmniejszenie śmiertelności ogólnej [3, 6, 8]. Autorzy innych badań sugerują anaboliczny wpływ na mięśnie szkieletowe $[4,9]$, działanie neuroprotekcyjne, $w$ tym poprawę funkcji werbalnych u pacjentów z chorobą Parkinsona $[4,10]$. Udowodniono związek między niedoborami witaminy $\mathrm{D}$ a chorobami układu sercowo naczyniowego — nadciśnieniem tętniczym, chorobą wieńcową, przerostem lewej komory serca oraz skurczową niewydolnością serca. Już w 1997 roku, na podstawie założenia, że proces rozwoju zwapnień w blaszkach miażdżycowych przypomina proces osteogenezy, przeprowadzono badanie związku między stężeniem $1,25(\mathrm{OH})_{2} \mathrm{D}_{3}$ a zaawansowaniem zwapnień $\mathrm{w}$ tętnicach wieńcowych $\mathrm{w}$ grupie 
wysokiego i pośredniego ryzyka choroby wieńcowej. Zaobserwowano istotną odwrotną korelację - wyższy poziom zwapnień współistnieje z niższym stężeniem $1,25(\mathrm{OH})_{2} \mathrm{D}_{3}[11]$. Z kolei fińscy naukowcy, badając grupę 2150 ochotników w wieku 3-18 lat, na podstawie ultrasonograficznego badania grubości kompleksu intima-media tętnicy szyjnej wewnętrznej (IMT, intima-media thickness), zaobserwowali, że niski poziom $25(\mathrm{OH}) \mathrm{D}$ w dzieciństwie skutkuje wyższym ryzykiem rozwoju chorób układu sercowo-naczyniowego w wieku dojrzałym [12].

\section{DIAGNOSTYKA}

Za najlepszy wykładnik zaopatrzenia organizmu $\mathrm{w}$ witaminę D uznaje się stężenie w osoczu metabolitu $25(\mathrm{OH}) \mathrm{D}$ o długim okresie półtrwania w surowicy krwi wyrażone w nanogramach na mililitr lub nanomolach na $\operatorname{litr}(1 \mathrm{ng} / \mathrm{ml}=2,5 \mathrm{nmol} / \mathrm{l})$. Standardem diagnostycznym powinno być równoczesne oznaczanie $25(\mathrm{OH}) \mathrm{D}_{2}$ oraz $25(\mathrm{OH}) \mathrm{D}_{3}$, czyli $25(\mathrm{OH}) \mathrm{D}$ całkowitej $[2,13,14]$. Oznaczenie stężenia aktywnego biologicznie $1,25(\mathrm{OH})_{2} \mathrm{D}$ jest wskazane w ograniczonych przypadkach, w tym chorobach ziarniniakowych (nadmierna ekspresja pozanerkowej hydroksylazy CYP27B1), pierwotnej nadczynności przytarczyc oraz niektórych nowotworach. Oznacza się je również w schorzeniach wynikających z defektu enzymu katabolizującego CYP24A1, takich jak idiopatyczna hiperkalcemia niemowląt, mogących prowadzić do nefrokalcynozy $[15,16]$. Powyższa grupa pacjentów powinna utrzymywać niższe wartości $25(\mathrm{OH}) \mathrm{D}$ niż zalecane dla populacji ogólnej (np. 20-25 ng/ml) [3]. W przypadku zaburzeń wapniowo-fosforanowych wskazana jest kontrola podstawowych parametrów ich gospodarki oraz stężenia $25(\mathrm{OH}) \mathrm{D}$ co 3 miesiące. W najnowszych zaleceniach nie rekomenduje się rutynowego oznaczenia poziomu witaminy D w populacji ogólnej. Wyjątek stanowią grupy ryzyka niedoboru witaminy $\mathrm{D}$ (tab. 1).

\section{SUPLEMENTACJA}

Według badań epidemiologicznych niedobór witaminy $\mathrm{D}$ w populacji europejskiej może obejmować 50-70\% społeczeństwa, a w Polsce nawet około 90\% [15, 17, 18]. Skłoniło to liczne towarzystwa naukowe do opracowania propozycji wytycznych diagnostyki i leczenia deficytów witaminy D. Ich stanowiska w sprawie stężenia $25(\mathrm{OH})$ D w osoczu jako celu prawidłowej suplementacji i leczenia różnią się zależnie od przyjętych założeń. Terapia bazująca na prewencji krzywicy oraz szeroko pojętej gospodarce wapniowo-fosforanowej, a co za tym idzie

Tabela 1. Wskazania do oceny stężenia 25(OH)D w osoczu w grupach ryzyka (na podstawie [15])

\section{Ws}

Zaburzenia metabolizmu wapniowo-fosforowego

Przewlekłe przyjmowa-
nie leków

Zaburzenia trawienia i wchłaniania

Choroby wątroby

Choroby nerek

Zaburzenia endokrynologiczne

\section{Zaburzenia wzrostu i} masy ciała

Zaburzenia rozwoju

Choroby alergiczne
Przykłady jednostek chorobowych

Krzywica

Osteomalacja

Osteoporoza

Bóle kostne

Deformacje kostne oraz wady postawy

Niskoenergetyczne złamania kości Aseptyczna martwica kości

Nieprawidłowa kalcemia

Kalciuria

Hiperfosfatemia i hipofosfatemia

Fosfaturia

Hipofosfatazja oraz hiperfosfatazja

Przewlekła steroidoterapia

Leczenie ketokonazolem

Terapia antyretrowirusowa

Leczenie przeciwpadaczkowe

Choroby zapalne jelit

Mukowiscydoza

Niewydolność wątroby

Cholestaza

Niealkoholowa stłuszczeniowa choroba wątroby (NAFLD, non-alcoholic fatty liver disease)

Stan po przeszczepieniu wątroby

Przewlekła choroba nerek

Wapnica nerek

Stan po przeszczepieniu nerek

Nadczynność i niedoczynność przytarczyc

Nadczynność i niedoczynność tarczycy

Cukrzyca typu 1

Niedobór hormonu wzrostu

Anoreksja

Wielogruczołowe zespoły autoimmunologiczne

Niski i wysoki wzrost

Otyłość

Kacheksja

Mózgowe porażenie dziecięce

Przewlekłe unieruchomienie

Autyzm

Stwardnienie rozsiane

Padaczka

Drgawki o nieznanej przyczynie

Miopatie

Dystrofie mięśniowe

Astma

Atopowe zapalenie skóry 
Tabela $1 \mathrm{~cd}$. Wskazania do oceny stężenia 25(OH)D w osoczu w grupach ryzyka (na podstawie [15])

$\begin{array}{ll}\begin{array}{ll}\text { Choroby autoimmuno- } \\ \text { logiczne }\end{array} & \begin{array}{l}\text { Kolagenozy } \\ \text { Reumatoidalne zapalenie stawów } \\ \text { Cukrzyca typu 1 } \\ \text { Choroba Hashimoto } \\ \text { Choroby autoimmunologiczne } \\ \text { skóry }\end{array} \\ & \text { Nawracające infekcje dróg odde- } \\ \text { Zaburzenia układu od- } & \text { Astma } \\ \text { pornościowego } & \text { Nawracające i przewlekłe stany } \\ & \text { zapalne w obrębie innych układów } \\ & \text { Nowotwory złośliwe niezależnie od } \\ \text { Nowotwory } & \text { lokalizacji, w tym nowotwory krwi } \\ & \text { i układu chłonnego, guzy } \\ & \text { Stan po leczeniu onkologicznym } \\ \text { Nadciśnienie tętnicze } & \text { Choroba niedokrwienna serca } \\ \text { Choroby układu serco- } & \text { Cukrzyca typu 2 } \\ \text { wo-naczyniowego } & \text { Otyłość } \\ \text { Zaburzenia metabo- } & \text { Zespół metaboliczny } \\ \text { liczne } & \text { Zaburzenia lipidowe }\end{array}$

prawidłowej funkcji układu kostnego, zakłada dążenie do poziomu $25(\mathrm{OH}) \mathrm{D}$ powyżej $20 \mathrm{ng} / \mathrm{ml}$, natomiast leczenie uwzględniające plejotropowe działanie witaminy D na inne układy organizmu wskazuje na docelowe stężenie 30-50 ng/ml [3]. Dodatkowym argumentem wspierającym uznanie tego poziomu witaminy $\mathrm{D}$ w osoczu za optymalny jest kinetyka 25-hydroksylazy. Wykazuje ona 50-procentową aktywność przy stężeniu 40 ng/ml $[15,19,20]$. W maju 2018 roku grono ekspertów opublikowało na łamach "Frontieres of Endocrinology” [15] aktualizację dotychczas obowiązujących zaleceń suplementacji witaminy D w Polsce. Eksperci upatrują przyczyn niedoborów tej witaminy w zdrowej populacji między innymi w obniżeniu syntezy skórnej związanej z trybem życia, procesami starzenia, stosowaniem filtrów słonecznych, stopniem pigmentacji skóry, szerokością geograficzną, zanieczyszczeniem powietrza oraz $\mathrm{w}$ niedostatecznej podaży witaminy $\mathrm{D} w$ diecie $[2,15]$. Już w 1822 roku polski lekarz i chemik Jędrzej Śniadecki zauważył istotną korelację między stopniem industrializacji i związanym z tym zanieczyszczeniem powietrza a częstszym występowaniem krzywicy u dzieci mieszkających w centrum Warszawy niż u tych z terenów wiejskich. Naturalne źródła witaminy $\mathrm{D}$ w diecie są bardzo ograniczone [21, 22]. Oszacowano, że prawidłowo zbilansowana dieta może zapewnić do $20 \%$ dziennego zapotrzebowania na witaminę D [15]. Trwają dyskusje na temat tego, czy obieg witaminy D wchłanianej z układu pokarmowego oraz produkowanej w skórze jest tożsamy. Zaobserwowano, że $25(\mathrm{OH}) \mathrm{D}_{3}$ produkowana w skórze utrzymuje się w osoczu 2-3 razy dłużej niż przyjęta doustnie i przyłącza się do DBP w 100\%. Z kolei doustne podanie cholekalcyferolu skutkuje przyłączeniem do chylomikronów, transportowanych następnie przez układ limfatyczny do układu żylnego, gdzie do DBP przyłącza się tylko około $60 \%$, a $40 \%$ jest usuwane z frakcją lipoprotein [21, 23]. Naturalne zasoby witaminy D są więc zapewniane głównie przez syntezę skórną pod wpływem promieni UVB (280-315 nm). Efektywna synteza skórna 25(OH)D jest możliwa w Polsce od maja do września, w godzinach 10:00-15:00, przy ekspozycji trwającej przez około 15 minut, obejmującej około $18 \%$ powierzchni ciała (np. przedramiona i podudzia) oraz przy założeniu niestosowania w tym czasie filtrów słonecznych. W miesiącach zimowych oraz latem w godzinach porannych i wieczornych wypukły kąt padania promieni słonecznych na powierzchnię ziemi powyżej 33 stopni szerokości geograficznej (Polska 49-54 $\mathrm{N}$ ) niemal całkowicie uniemożliwia skórną produkcję witaminy D $[15,21]$. Dodatkowo stosowanie filtrów przeciwsłonecznych ogranicza penetrację ludzkiej skóry przez promienie UV. Badania dowodzą, że ze względu na różne właściwości fizyczne (odbijanie promieni UV) oraz chemiczne (pochłanianie promieni UV) nawet filtry o jednakowym wskaźniku ochrony przeciwsłonecznej (SPF, sun protection factor) różnią się stopniem zapewnianej protekcji [24]. Uważa się jednak, że te ze wskaźnikiem SPF równym 30 i wyższym ograniczają wchłanianie promienia UVB nawet do 95-98\% [21, 25]. Zalecana warstwa $2 \mathrm{mg}$ filtra na $\mathrm{cm}^{2}$ skóry może skutkować aż 99-procentowym zmniejszeniem produkcji witaminy D na tym obszarze $[24,26,27]$. Średnia grubość warstwy filtra nakładanego przez nas na skórę to jednak tylko $0,8-1 \mathrm{mg} / \mathrm{cm}^{2}$, a więc niemal 2-krotnie mniej niż wartości zalecane. $Z$ większości badań wynika zatem, że w powyższych warunkach stosowanie filtrów z niższym wskaźnikiem ochrony przeciwsłonecznej $(\mathrm{SPF}<30)$ nie zapobiega całkowicie produkcji witaminy D w skórze [24, 28-35]. W związku ze znaczną trudnością w opieraniu się na naturalnych źródłach witaminy D zaleca się jej suplementację od pierwszych dni życia niezależnie od sposobu karmienia aż do później starości. Rozpoczęcie suplementacji należy poprzedzić oszacowaniem prawdopodobieństwa nadwrażliwości na witaminę D. Konieczna jest ocena 
Tabela 2. Zalecenia suplementacji witaminy D w populacji osób zdrowych oraz grup ryzyka niedoborów (na podstawie [15])

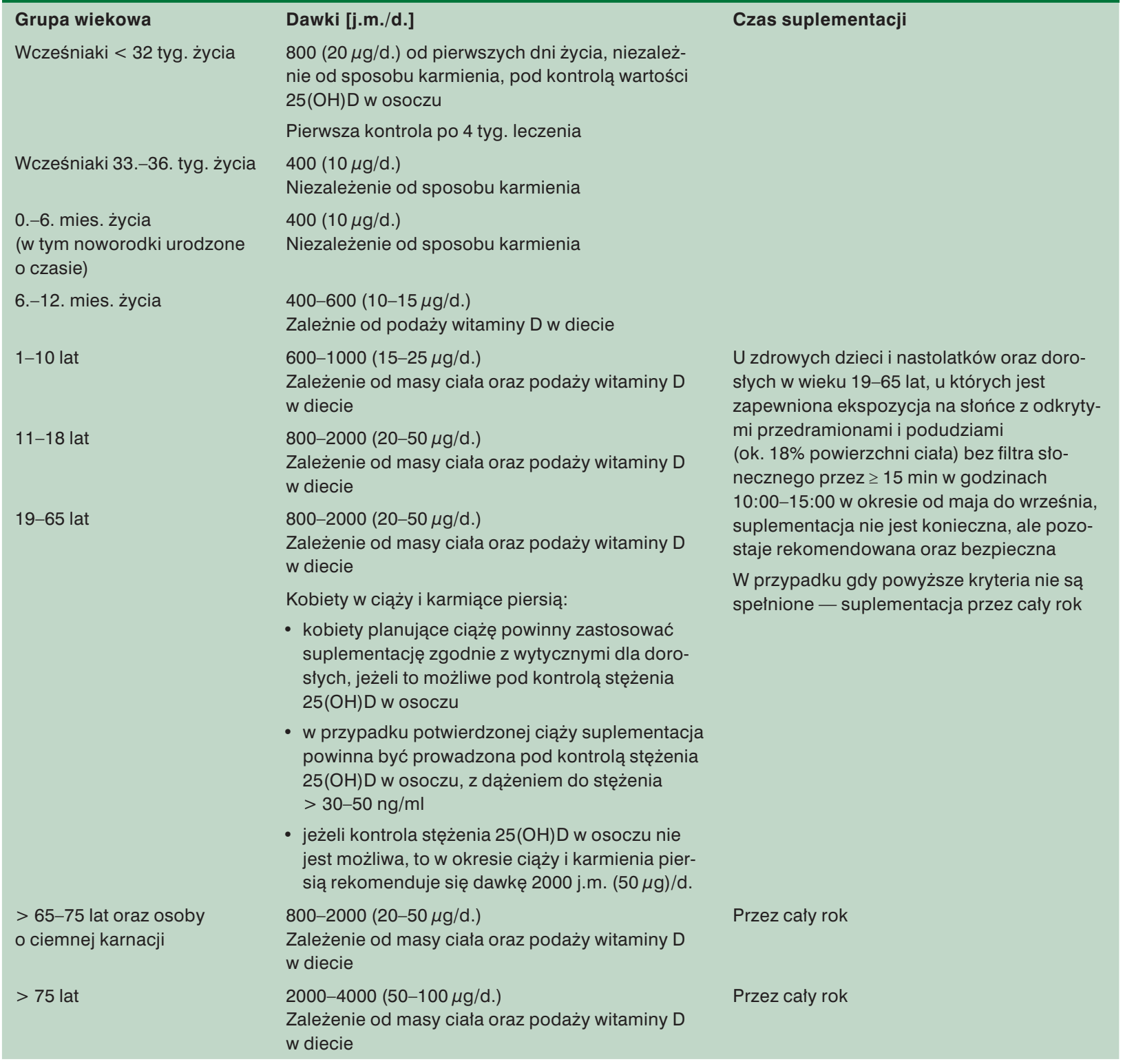

Tabela 3. Maksymalne dobowe dawki witaminy D w populacji osób zdrowych o prawidłowej masie ciala rekomendowane przez European Food Safety Authority (na podstawie [2])

$\begin{array}{lc}\text { Grupa wiekowa } & \text { Dawka }[j . m . / d .] \\ <1 . \text { r.ż. } & 1000(25 \mu \mathrm{g} / \mathrm{d} .) \\ 1-10 \text { lat } & 2000(50 \mu \mathrm{g} / \mathrm{d} .) \\ 11-18 \text { lat } & 4000(100 \mu \mathrm{g} / \mathrm{d} .) \\ >18 \text { lat } & 4000(100 \mu \mathrm{g} / \mathrm{d} .)\end{array}$

wywiadu rodzinnego oraz dotychczas stwierdzonych zaburzeń w gospodarce wapniowo-fosforanowej. Dawki profilaktyczne powinny zależeć od wieku, masy ciała, stopnia nasłonecznienia związanego z porą roku i ekspo- zycji na słońce oraz uwarunkowań indywidualnych, tj. diety i stylu życia [15] (tab. 2). W przypadku osób otyłych (wskaźnik masy ciała [BMI, body mass index] > 90. percentyla dla płci i wieku u dzieci i młodzieży oraz BMI $>30 \mathrm{~kg} /$ $/ \mathrm{m}^{2} \mathrm{u}$ dorosłych) należy rekomendować podwojone dawki witaminy D dla danego przedziału wiekowego o prawidłowej masie ciała. W grupach ryzyka niedoboru witaminy D (tab. 1) suplementacja powinna być prowadzona pod kontrolą stężenia $25(\mathrm{OH}) \mathrm{D}$ w osoczu, z dążeniem do wartości powyżej $30 \mathrm{ng} / \mathrm{ml}$ do $50 \mathrm{ng} / \mathrm{ml}$. Jeżeli oznaczenie stężenia $25(\mathrm{OH}) \mathrm{D}$ w osoczu nie jest możliwe, to dawkowanie powinno odpowiadać maksymalnym zalecanym dawkom dla danej płci i wieku. Ze względu na długi okres półtrwania 25(OH)D w osoczu 


\section{Tabela 4. Wskazania terapeutyczne zależnie od stężenia witaminy D w osoczu (na podstawie [2])}

Stężenie 25(OH)D w osoczu [ng/ml]

\section{Status}

$<10(25 \mathrm{nmol} / \mathrm{l})$

Ciężki niedobór

Niedobór

20-30 (50-75 nmol/l)

30-50 (75-125 nmol/l)

$>50-75 \mathrm{ng} / \mathrm{ml}$

$75-100 \mathrm{ng} / \mathrm{ml}(187,5-250 \mathrm{nmol} / \mathrm{l})$

$>100(250 \mathrm{nmol} / \mathrm{l})$

$100(250 \mathrm{nmol} / \mathrm{l})$

oraz współistnienie objawów: hiperkal-

cemia, hiperkalciuria, supresja PTH

\section{Wskazania}

Leczenie przez 3 mies. lub do czasu uzyskania stężenia 25(OH)D > 30-50 ng/ml, następnie dawki podtrzymujące (np. wg zaleceń dla populacji ogólnej)

Dawkowanie zależnie od wieku oraz masy ciała:

- 0.-12. mies. życia - 2000 j.m./d.

- 1.-10. r.ż. - 3000-6000 j.m./d.

- 10 r.ż. -6000 j.m./d.

Kontrola stężenia 25(OH)D po 1-3 mies.

Prawidłowo prowadzona wcześniejsza suplementacja —zwiększenie dawki o $100 \%$

Brak wcześniejszej suplementacji - maksymalne dawkowanie odpowiednie dla wieku i masy ciała wg wytycznych dla populacji ogólnej

Wskazane osiągnięcie stężenia optymalnego po 3 mies. Kontrola stężenia 25(OH)D po 3 mies.

Stężenie suboptymalne

Stężenie optymalne

Stężenie wysokie

Stężenie wysokie

Stężenie toksyczne

Zatrucie witamina D
Prawidłowo prowadzona wcześniejsza suplementacja — zwiększenie dawki o $50 \%$

Brak wcześniejszej suplementacji —dawkowanie odpowiednie dla wieku i masy ciała wg wytycznych dla populacji ogólnej

Kontrola 25(OH)D po 6 mies.

Utrzymanie dotychczasowej dawki dobowe

Prawidłowo prowadzona wcześniejsza suplementacja —zmniejszenie dawki o $50 \%$

Suplementacja w dawkach większych niż zalecenie wstrzymanie na 1 mies., nastepnie dawkowanie wg zaleceń dla populacji ogólnej

Kontrola 25(OH)D po 3 mies.

Wstrzymanie suplementacji na 1-2 mies.

U noworodków, niemowląt i małych dzieci oznaczenie stężenia Ca w osoczu i w moczu oraz wykluczenie nadwrażliwości na witaminę $\mathrm{D}$, ponowna kontrola stężenia 25(OH)D

Ponowna suplementacja w dawkach minimalnych wg wytycznych dla populacji ogólnej ponownie możliwa po 1-2 mies. lub, u noworodków, niemowląt i małych dzieci, po uzyskaniu stężenia 25(OH)D $\leq 50 \mathrm{ng} / \mathrm{ml}$

Niezwłoczne wstrzymanie suplementacji

Ocena stężenia Ca w moczu i w osoczu

Kontrola 25(OH)D co miesiąc do czasu uzyskania stężenia $\leq 50 \mathrm{ng} / \mathrm{ml}$

Ponowna suplementacja w dawkach wg wytycznych dla populacji ogólnej ponownie możliwa po uzyskaniu normokalcemii, normokalciuri oraz stężenia 25(OH)D $\leq 50 \mathrm{ng} / \mathrm{ml}$, poprzedzonych wykluczeniem nadwrażliwości na witaminę $\mathrm{D}$

Niezwłoczne leczenie

25(OH)D - 25-hydroksywitamina D; Ca — wapń; PTH — parathormon

oraz gromadzenie w tkankach podaż witaminy D nie musi się odbywać codziennie, a może następować na przykład raz w tygodniu [2]. Preparaty witaminy D należy przyjmować razem z posiłkiem.
Mimo rozbieżności dotyczących optymalnego stężenia witaminy $\mathrm{D}$ towarzystwa naukowe są zgodne co do maksymalnych dobowych dawek dla zdrowej populacji ogólnej, które nie powodują działań niepożądanych, oraz 
przyjmują stanowisko European Food Safety Authority (tab.3). Maksymalne tolerowane dawki nie powinny być mylone $\mathrm{z}$ rekomendowanym dawkowaniem $\mathrm{w}$ czasie dobrze kontrolowanego leczenia niedoboru witaminy D.

\section{LECZENIE NIEDOBORU}

Leczenie potwierdzonego laboratoryjnie niedoboru witaminy D, czyli stężenia $25(\mathrm{OH}) \mathrm{D}$ poniżej $20 \mathrm{ng} / \mathrm{ml}$ (50 nmol/l), powinno trwać do uzyskania wartości 30-50 ng/ml (75-125 nmol/l) [2, 15]. Każdorazowo należy zweryfikować poprawność dotychczasowego dawkowania oraz ocenić przestrzeganie przez chorego zaleceń lekarskich. Pojedyncza dawka wysycająca nie jest wskazana nawet w przypadku dużego niedoboru. Szczegółowe wskazania terapeutyczne w zależności od stężenia $25(\mathrm{OH}) \mathrm{D}$ w osoczu oraz zalecane dawki witaminy D podano w tabeli 4 . W przypadku niedoboru ze współistniejącymi objawami z zakresu układu kostno-szkieletowego, takimi jak deformacje oraz bóle kostne lub niskoenergetyczne złamania patologiczne, konieczne jest oznaczenie oraz monitorowanie parametrów gospodarki wapniowo-fosforanowej. Należy oznaczyć stężenia wapnia, fosforu, kreatyniny, fosfatazy alkalicznej i parathormonu w surowicy krwi oraz stężenie wapnia w moczu. Jeżeli to możliwe, wskazane jest badanie gęstości kości. Zarówno w czasie profilaktyki, jak i leczenia niedoboru witaminy D wskazana jest odpowiednia podaż wapnia $\mathrm{w}$ diecie lub suplementacja farmakologiczna soli wapnia w dawkach podzielonych, przyjmowanych z posiłkiem.

\section{PODSUMOWANIE}

Mimo wielu rekomendacji suplementacja witaminy D jest przestrzegana rygorystycznie tylko w pierwszych miesiącach życia [2]. Choć liczba przyjmowanych suplementów zwiększa się, to - jak do tej pory — nie ma to przełożenia na istotny wzrost średniego poziomu zaopatrzenia w 25(OH)D [3]. Być może, wiąże się to z wciąż obecnym niepokojem związanym z toksycznym działaniem dużych dawek witaminy D. Należy pamiętać, że podstawą wyboru odpowiedniej strategii terapeutycznej powinna być analiza indywidualnego statusu zdrowotnego pacjenta, jego wieku, masy ciała, miejsca życia, nawyków żywieniowych oraz kulturowych. Wzmacnia to pozycje zaleceń opracowanych przez towarzystwa naukowe w poszczególnych regionach, a zalecenia globalne odnosi raczej do leczenia potwierdzonego niedoboru oraz konkretnych jednostek chorobowych. Nowe światło na ten problem mogą rzucić randomizowane badania dotyczące suplementacji. Dostarczą one odpowiedzi na pytanie, czy dzienna suplementacja witaminy $\mathrm{D}_{3}$ (2000 j.m.) obniża ryzyko rozwoju nowotworów, chorób układu sercowo-naczyniowego i udaru mózgu u osób bez ich wcześniejszego wywiadu oraz czy zmniejsza śmiertelność.

\section{KONFLIKT INTERESÓW}

Autorzy nie zgłaszają potencjalnego konfliktu interesów.

\section{PIŚMIENNICTWO}

1. Anuszewska EL. Nowe spojrzenie na witaminę D. Gaz Farm. 2011; 2: $32-35$

2. Płudowski P, Karczmarewicz E, Bayer M, et al. Practical guidelines for the supplementation of vitamin $D$ and the treatment of deficits in Central Europe - recommended vitamin D intakes in the general population and groups at risk of vitamin D deficiency. Endokrynol Pol. 2013; 64(4): 319-327, indexed in Pubmed: 24002961.

3. Pludowski P, Holick MF, Grant WB, et al. Vitamin D supplementation guidelines. J Steroid Biochem Mol Biol. 2018; 175: 125-135, doi: 10.1016/j.jsbmb.2017.01.021, indexed in Pubmed: 28216084.

4. Piotrowska A, Wierzbicka J, Żmijewski MA. Vitamin D in the skin physiology and pathology. Acta Biochim Pol. 2016; 63(1): 17-29, doi: 10.18388/abp.2015_1104, indexed in Pubmed: 26824295

5. Haussler MR, Jurutka PW, Mizwicki M, et al. Vitamin D receptor (VDR)-mediated actions of $1 \alpha, 25(\mathrm{OH})_{2}$ vitamin $\mathrm{D}_{3}$ : genomic and non-genomic mechanisms. Best Pract Res Clin Endocrinol Metab. 2011; 25(4): 543-559, doi: 10.1016/j.beem.2011.05.010, indexed in Pubmed: 21872797

6. Pludowski P, Holick MF, Pilz S, et al. Vitamin D effects on musculoskeletal health, immunity, autoimmunity, cardiovascular disease, cancer, fertility, pregnancy, dementia and mortality-a review of recent evidence. Autoimmun Rev. 2013; 12(10): 976-989, doi: 10.1016/j. autrev.2013.02.004, indexed in Pubmed: 23542507.

7. Souberbielle JC, Body JJ, Lappe JM, et al. Vitamin D and musculoskeletal health, cardiovascular disease, autoimmunity and cancer: recommendations for clinical practice. Autoimmun Rev. 2010; 9(11): 709-715, doi: 10.1016/j.autrev.2010.06.009, indexed in Pubmed: 20601202

8. Garland CF, Kim JJ, Mohr SB, et al. Meta-analysis of all-cause mortality according to serum 25-hydroxyvitamin D. Am J Public Health. 2014; 104(8): e43-e50, doi: 10.2105/AJPH.2014.302034, indexed in Pubmed: 24922127.

9. Okuno $\mathrm{H}$, Kishimoto $\mathrm{KN}$, Hatori $\mathrm{M}$, et al. $1 \alpha, 25$-dihydroxyvitamin $\mathrm{D}_{3}$ enhances fast-myosin heavy chain expression in differentiated C2C12 myoblasts. Cell Biol Int. 2012; 36(5): 441-447, doi: 10.1042/ /CBI20100782, indexed in Pubmed: 22276695.

10. Peterson AL, Murchison C, Zabetian C, et al. Memory, mood, and vitamin D in persons with Parkinson's disease. J Parkinsons Dis. 2013; 3(4): 547-555, doi: 10.3233/JPD-130206, indexed in Pubmed: 24081441

11. Watson KE, Abrolat ML, Malone LL, et al. Active serum vitamin D levels are inversely correlated with coronary calcification. Circulation. 1997; 96(6): 1755-1760, indexed in Pubmed: 9323058

12. Juonala M, Voipio A, Pahkala K, et al. Childhood 25-OH vitamin D levels and carotid intima-media thickness in adulthood: the cardiovascular risk in young Finns study. J Clin Endocrinol Metab. 2015; 100(4): 1469-1476, doi: 10.1210/jc.2014-3944, indexed in Pubmed: 25668290

13. Singh RJ, Taylor RL, Reddy GS, et al. C-3 epimers can account for a significant proportion of total circulating 25-hydroxyvitamin $D$ in 
infants, complicating accurate measurement and interpretation of vitamin D status. J Clin Endocrinol Metab. 2006; 91(8): 3055-3061, doi: 10.1210/jc.2006-0710, indexed in Pubmed: 16720650.

14. Lensmeyer G, Poquette M, Wiebe D, et al. The C-3 epimer of 25-hydroxyvitamin $\mathrm{D}(3)$ is present in adult serum. J Clin Endocrinol Metab. 2012; 97(1): 163-168, doi: 10.1210/jc.2011-0584, indexed in Pubmed: 22013102.

15. Rusińska A, Płudowski P, Walczak M, et al. Vitamin D supplementation guidelines for general population and groups at risk of vitamin D deficiency in Poland - recommendations of the Polish Society of Pediatric Endocrinology and Diabetes and the Expert Panel With Participation of National Specialist Consultants and Representatives of Scientific Societies - 2018 update. Front Endocrinol (Lausanne). 2018; 9: 246, doi: 10.3389/fendo.2018.00246, indexed in Pubmed: 29904370.

16. Kaufmann M, Morse N, Molloy BJ, et al. Mutations in CYP24A1 and idiopathic infantile hypercalcemia. N Engl J Med. 2011; 365(5): 410-421, doi: 10.1056/NEJMoa1103864, indexed in Pubmed: 21675912.

17. Hilger J, Friedel A, Herr R, et al. A systematic review of vitamin D status in populations worldwide. Br J Nutr. 2014; 111(1): 23-45, doi: 10.1017/ /S0007114513001840, indexed in Pubmed: 23930771.

18. Karczmarewicz E, Czekuc-Kryskiewicz E, Płudowski P. Effect of vitamin D status on pharmacological treatment efficiency: impact on cost-effective management in medicine. Dermatoendocrinol. 2013; 5(2) 299-304, doi: 10.4161/derm.25279, indexed in Pubmed: 24194969.

19. Norman AW. From vitamin $D$ to hormone $D$ : fundamentals of the vitamin D endocrine system essential for good health. Am J Clin Nutr. 2008; 88(2): 491S-499S, doi: 10.1093/ajcn/88.2.491S, indexed in Pubmed: 18689389.

20. Hollis BW, Wagner CL, Drezner MK, et al. Circulating vitamin D3 and 25-hydroxyvitamin $D$ in humans: an important tool to define adequate nutritional vitamin D status. J Steroid Biochem Mol Biol. 2007; 103(3-5): 631-634, doi: 10.1016/j.jsbmb.2006.12.066, indexed in Pubmed: 17218096

21. Wacker M, Holick MF. Sunlight and vitamin D: a global perspective for health. Dermatoendocrinol. 2013; 5(1): 51-108, doi: 10.4161/ /derm.24494, indexed in Pubmed: 24494042.

22. Mozołowski W. Jędrzej Śniadecki (1768-1838) on the cure of rickets. Nature. 1939; 143(3612): 121-121, doi: 10.1038/143121a0.

23. Haddad JG, Matsuoka LY, Hollis BW, et al. Human plasma transport of vitamin D after its endogenous synthesis. J Clin Invest. 1993; 91(6): 2552-2555, doi: 10.1172/JCl116492, indexed in Pubmed: 8390483.
24. Grigalavicius M, lani V, Juzeniene A. Layer thickness of SPF 30 sunscreen and formation of pre-vitamin D. Anticancer Res. 2016; 36(3): 1409-1415, indexed in Pubmed: 26977044.

25. Holick MF. Vitamin D deficiency. N Engl J Med. 2007; 357(3) : 266-281, doi: 10.1056/NEJMra070553, indexed in Pubmed: 17634462.

26. Webb AR. Who, what, where and when-influences on cutaneous vitamin D synthesis. Prog Biophys Mol Biol. 2006; 92(1): 17-25, doi: 10.1016/j.pbiomolbio.2006.02.004, indexed in Pubmed: 16766240.

27. Matsuoka LY, Ide L, Wortsman J, et al. Sunscreens suppress cutaneous vitamin D3 synthesis. J Clin Endocrinol Metab. 1987; 64(6): 1165-1168, doi: 10.1210/jcem-64-6-1165, indexed in Pubmed: 3033008.

28. Stenberg $C$, Larkö O. Sunscreen application and its importance for the sun protection factor. Arch Dermatol. 1985; 121(11): 1400-1402, indexed in Pubmed: 4051527

29. Bech-Thomsen N, Wulf HC. Sunbathers' application of sunscreen is probably inadequate to obtain the sun protection factor assigned to the preparation. Photodermatol Photoimmunol Photomed. 1992; 9(6): 242-244, indexed in Pubmed: 1343224

30. Neale R, Williams G, Green A. Application patterns among participants randomized to daily sunscreen use in a skin cancer prevention trial. Arch Dermatol. 2002; 138(10): 1319-1325, indexed in Pubmed: 12374537.

31. Szepietowski JC, Nowicka D, Reich A, et al. Application of sunscreen preparations among young Polish people. J Cosmet Dermatol. 2004; 3(2): 69-72, doi: 10.1111/j.1473-2130.2004.00119.x, indexed in Pubmed: 17147558.

32. Reich A, Harupa M, Bury M, et al. Application of sunscreen preparations: a need to change the regulations. Photodermatol Photoimmunol Photomed. 2009; 25(5): 242-244, doi: 10.1111/j.1600-0781.2009.00450.x, indexed in Pubmed: 19747242.

33. Petersen B, Datta P, Philipsen PA, et al. Sunscreen use and failure - on site observations on a sun-holiday. Photochem Photobiol Sci. 2013; 12(1): 190-196, doi: 10.1039/c2pp25127b, indexed in Pubmed: 23023728.

34. Autier P, Boniol M, Severi G, et al. European Organizatin for Research and Treatment of Cancer Melanoma Co-operative Group. Quantity of sunscreen used by European students. Br J Dermatol. 2001; 144(2): 288-291, indexed in Pubmed: 11251560.

35. Diaz A, Neale RE, Kimlin MG, et al. The children and sunscreen study: a crossover trial investigating children's sunscreen application thickness and the influence of age and dispenser type. Arch Dermatol. 2012; 148(5): 606-612, doi: 10.1001/archdermatol.2011.2586, indexed in Pubmed: 22250190. 